\title{
Analýza úrovně antropometrických a silových charakteristik tenistů a tenistek ve věku 11-12 let
}

\section{Analysis of the level of anthropometric and strength characteristics of male and female players aged 11-12}

\author{
Jiří Pačes ${ }^{1}$, Jiří Zháněl', Tomáš Vodička' ${ }^{1}$, Pavel Mudra' ${ }^{1}$, Martin Vilím¹ , Ondřej Hubáček ${ }^{2}$ \\ Fakulta sportovních studií, Masarykova univerzita, Brno' \\ Fakulta tělesné kultury, Palackého univerzita, Olomouc ${ }^{2}$
}

\begin{abstract}
Abstrakt:
Problematikou významu silových schopností ve sportu a v tenisu se zabývá mnoho autorů, v tenisu se síla projevuje především v razanci úderů, rychlosti podání a lokomoci pohybu. Cílem příspěvku je analýza úrovně základních antropometrických a silových charakteristik tenistů a tenistek, posouzení intersexuálních rozdílů a zjištění míry závislosti mezi antropometrickými a silovými charakteristikami. Výzkumný soubor je tvořen českými tenisty $(n=221)$ a tenistkami $(n=193)$ ve věku 11,0-12,9 let. Výzkumná data byla získána v letech 200-2010 pomocí testové baterie TENDIAG 1. Analýza výzkumných dat prokázala, že pocházejí z normálního rozložení. Úroveň základních antropometrických a silových proměnných je vyjádřena pomocí základních statistických charakteristik pro jednotlivé proměnné: soubor tenistů $(n=221$, tělesná výška: $V=155,10 \pm 7,62$, hmotnost: $H=43,50 \pm 6,68$, maximální síla herní ruky: $M S=25,14 \pm 4,59$, relativní síla herní ruky: $R S=0,58 \pm 0,09)$, soubor tenistek $(n=193$, tělesná výška: $V=154,60 \pm 6,94$, hmotnost: $H=43,49 \pm 7,17$, maximální síla herní ruky: $M S=23,08 \pm 4,61$, relativní síla herní ruky: $R S=0,53 \pm 0,09)$. Věcná významnost intersexuálních rozdílů byla posouzena pomocí Cohenova $d$, věcně významné rozdíly byly prokázány pouze $v$ př́padě $R S(d=0,56$, strední efekt) a MS ( $d=0,45$, nízký efekt). Věcně významná závislost byla u souboru tenistů prokázána mezi $\mathrm{VaH}\left(r=0,71, r^{2}=0,50\right.$; střední efekt), dále mezi V a MS $\left(r=0,59, r^{2}=0,35\right.$; střední efekt) a mezi H a MS $\left(r=0,59, r^{2}=0,35\right.$, střední efekt). U souboru tenistek byla prokázána věcně významná závislost mezi $\mathrm{VaH}\left(r=0,75, r^{2}=0,56\right.$; střední efekt), dále mezi H a MS $\left(r=0,64, r^{2}=0,41\right.$, střední efekt) a rovněž mezi maximální a relativní silou $\left(r=0,58, r^{2}=0,34\right.$; střední efekt).
\end{abstract}

\section{Abstract:}

The issues of the significance of strength capabilities in sport and tennis are dealt with by many authors, in tennis, the strength of the playing arm primarily manifests in the speed of strokes, serve and locomotion movement. The goal of this paper is analysis of basic anthropometric and strength levels of male and female players', comparisons and evaluation of inter-gender differences of anthropometric and strength characteristic. The research sample consists of Czech junior male tennis players $(n=221)$ and female players $(n=193)$ in the ages between 11.0 and 12.9 years. The data for this research were gathered during 2000-2010 period by regular testing using a test battery TENDIAG 1. Analysis of acquired data shows normal distribution characteristics. Values of measured anthropometric and strength levels statistic characteristic variables in the set of male tennis players $(n=221$, body height: $H=155.10 \pm 7.62$, body weight: $W=43.50 \pm 6.68$, strength of playing hand: $S H=25.14 \pm 4.59$, relative strength of playing hand: $R S=0.58 \pm 0.09$ ) and female tennis players ( $n=193$, body height: $H=154.60 \pm 6.94$, body weight: $W=43.49 \pm 7.71$, maximum strength of playing hand: $S H=23.08 \pm 4.61$, relative strength of playing hand $R S=0.53 \pm 0.09$ ).

Inter-gender differences between male and female tennis players were assessed using Cohen's $d$ values, substantively significant differences in mean values between male and female players files were detected only in the relative strength of gaming hand ( $d=0.56$, mean effect) and maximum strength level of game hand ( $d=0.45$, low effect). Size of effect was significant in the sample tennis 
players demonstrated between $H$ and $W\left(r=0.71, r^{2}=0.50\right.$; mean effect), among $H$ and $M S(r=0.59$, $r^{2}=0.35$; mean effect) and between MS and $W\left(r=0.59, r^{2}=0.35\right.$, mean effect). In a group of female tennis players has been demonstrated size of effect relation between $\mathrm{H}$ and $W\left(r=0.75, r^{2}=0.56\right.$; mean effect), among $W$ and $M S\left(r=0.64, r^{2}=0.41\right.$, mean effect) and also between the maximum and the relative strength $\left(r=0.58, r^{2}=0.34\right.$; mean effect $)$.

\section{Klíčová slova:}

intersexuální diference, ruční dynamometr, síla, tenis, test

\section{Keywords:}

inter-gender difference, hand dynamometer, strength, tennis, test

Článek vznikl na Masarykově univerzitě v rámci projektu „,Analýza vybraných faktorů ovlivňujících herní výkon v tenisu " čislo 2015/51/MUNI/A/1286/2014 podpořeného z prostředkủ účelové podpory pro specifický vysokoškolský výzkum, kterou poskytlo MŠMT v roce 2015.

\section{Úvod}

Současný závodní tenis klade vysoké požadavky na kondiční připravenost, mezi nejdůležitější motorické schopnosti ovlivňující významně sportovní výkon v tenisu patř́i síla, rychlost a koordinace. Silová schopnost se projevuje zejména $\mathrm{v}$ razanci jednotlivých tenisových úderů. Potřebná úroveň obecné síly vytváŕí podmínky nezbytné pro harmonický tělesný rozvoj a je základem pro sílu speciální. Ta je důležitá pro tenisové údery, $\mathrm{k}$ rychlému pohybu hráče po dvorci i ke skokům různými směry při zákrocích na síti (Schönborn, 2012; Hohmann et al., 2010).

V tenise je důležitá především rychlá a výbušná (explozivní) síla, která je určována nejen velikostí síly, ale i časovým úsekem, za kterou sportovec dosáhne určité procento své maximální síly. Rychlá síla se v tenise projevuje při pohybu po dvorci a při většině tenisových úderů. Explozivní síla se projevuje zejména při razantních úderech se snahou o dosažení př́mého bodu a při lokomoci na kurtu (Dovalil et al., 2012).

Charakter tenisu je v posledním desetiletí výrazně dynamičtější, silovější a rychlejší. Je to ovlivněno jak novými technologiemi použitými při výrobě tenisových raket a strun, ale také důrazem na kondiční príípravu hráčů. Podle autorů Roetert a Kovacs (2011) je dnešním tenise používáno mnohem více vítězných úderu $\mathrm{z}$ otevřeného postavení, které klade na hráče větší silové nároky spojené s vysokým zatížením kloubního a svalového systému. Svaly mají v tenise za úkol kromě vyvinutí síly i jejich následné excentrické zpomalení při dotahovaní jednotlivých úderů. Moderní rakety dovolují mnohem větší ulnární a radiální odchylky a $\mathrm{z}$ tohoto důvodu častěji dochází k poranění zápěstí. Proto je zcela nezbytné rovnoměrné posilování extenzorů a flexorů. Podle autorů Reid et al. (2003) generují silové schopnosti rychlost a sílu jednotlivých tenisových úderů; dosažení vysoké úrovně jejich rychlosti, razance a variability není možné bez dobře rozvinuté úrovně silových schopností. $\mathrm{S}$ ohledem na skutečnost, že se tenis hraje na třech různých površích (tvrdý povrch na betonových podkladech, antuka, tráva) umožňuje vysoká úroveň silových schopností optimální přizpůsobení rozličným požadavkům. Tvrdý povrch vyžaduje vysokou úroveň elastické a reaktivní síly, schopnost rychlé akcelerace a de-akcelerace těla. Hra na antukovém povrchu (podobně jako na trávnatém) je charakterizována vysokými požadavky na stabilitu, isometrickou a excentrickou svalovou kontrakci a vyžaduje větší dynamiku (Reid \& Schneiker, 2008). Optimální rozvoj silových schopností hraje zásadní roli při vývoji závodního hráče ze dvou hledisek - jednak snižuje možnost poranění a tím prodlužuje herní karieru, dále ovlivňuje zlepšení výkonnosti a tím zvyšuje karierní produktivitu (Reid et al., 2003). Dobrá úroveň síly nejenže má vliv na celkovou výkonnost, ale umožňuje i větší kontrolu tenisové rakety a tedy přesnější odehraní míče, což je rychlém a útočném způsobu hry velmi důležité. Reid et al. (2003) uvádějí, že úroveň silových schopností by měla být v harmonii s technickými, taktickými a psychologickými dispozicemi hráče. 
Výzkumem síly v různých sportech a u různých skupin populace se zabývala řada autorů (Carrasco et al., 2010; Gulías-González et al., 2014; Hanten, 1999; Innes et al., 1999; Reid, et al., 2003; Reid, \& Schneiker, 2008), často používanou výzkumnou metodou zjišt'ování úrovně maximální síly rukou je testování pomocí ručních dynamometrů. Jak uvádí Innes (1999), používané ruční dynamometry mohou být hydraulické (např. Jamar, USA), pneumatické (např. Baseline Tekdyne, USA) nebo mechanické (např. Takei, Japan). Maximální síla je důležitým předpokladem nejen úspěšnosti ve sportu, ale je také indikátorem tělesné zdatnosti obyvatelstva a je často využívaná při posouzení účinnosti rehabilitačních procedur v lékařství (Massey-Westrop, et al., 2004).

\section{Metodika}

Výzkumným záměrem bylo zjištění úrovně maximální síly rukou juniorských tenistů a tenistek při pravidelném testování výkonnostních předpokladů v rámci dlouhodobého projektu Českého tenisového svazu. Testování maximální síly rukou je jedním z testů testové baterie TENDIAG 1 (Zháněl et al., 2000). Při výzkumu realizovaném v letech $2000-2010$ byla zjištována úroveň maximální síly herní ruky českých juniorských tenistů $(\mathrm{n}=221)$ a tenistek $(\mathrm{n}=193)$ ve věku $11,0-12,9$ let pomocí mechanického ručního dynamometru (Grip D, Takei, Japan, výsledky jsou uváděny kilopondech). Relativní síla byla vypočítána jako poměr maximální síly na kilogram tělesné hmotnosti. Probandi prováděli 2 pokusy ve stoji (paže natažená podél těla, bez jeho doteku), za výsledek byl považován lepší z nich. Dále byla zjišt'ována úroveň dvou základních antropometrických znaků (tělesná výška a hmotnost).

\section{Výzkumné otázky:}

1. Jaká je úroveň síly a základních antropometrických znaků tenistů a tenistek ve věku 11-12 let?

2. Existují významné intersexuální rozdíly v úrovni síly a základních antropometrických znaků?

3. Lze prokázat významnou závislost mezi úrovní síly a základních antropometrických znaků?

\section{Cíle výzkumu:}

1. Pomocí statistické analýzy výzkumných dat zjistit úroveň maximální síly tenistů a tenistek a porovnat je s publikovanými údaji.

2. Zjistit intersexuální rozdíly mezi souborem tenistů a tenistek stejného věku.

3. Posoudit významnost vztahu mezi silou a základními antropometrickými znaky.

\section{Výsledky}

Normalita rozložení výzkumných dat byla ověrena pomocí Kolmogorov-Smirnova testu, bylo prokázáno, že naměřená data u hráčů i hráček pocházejí z normálního rozložení. Základní statistické charakteristiky souborů tenistů $(n=221)$ a tenistek $(n=193)$ jsou uvedeny v tabulce 1 .

Tabulka 1. Základní statistické charakteristiky sledovaných proměnných

\begin{tabular}{|l|c|c|c|c|c|c|c|c|}
\hline Soubor & \multicolumn{4}{|c|}{ Tenisté $(\mathbf{n}=\mathbf{2 2 1})$} & \multicolumn{4}{c|}{ Tenistky (n= 193) } \\
\hline Proměnné/SCH & $\mathbf{M}$ & SD & $\min$ & $\max$ & $\mathbf{M}$ & SD & $\min$ & max \\
\hline Věk & 12,03 & 0,54 & 11,00 & 12,90 & 11,98 & 0,54 & 11,00 & 12,90 \\
\hline Výška (cm) & 155,10 & 7,62 & 140,00 & 178,00 & 154,60 & 6,94 & 135,00 & 172,00 \\
\hline Hmotnost $(\mathbf{k g})$ & 43,50 & 6,68 & 30,00 & 72,60 & 43,49 & 7,17 & 28,20 & 66,80 \\
\hline MS (kp) & 25,14 & 4,59 & 12,80 & 40,70 & 23,08 & 4,61 & 12,40 & 43,30 \\
\hline RS & 0,58 & 0,09 & 0,33 & 0,80 & 0,53 & 0,09 & 0,34 & 0,98 \\
\hline
\end{tabular}

Vysvětlivky:

$M$... aritmetický průměr

SD ... smèrodatná odchylka 
MS ... maximální síla herní ruky

$R S$... relativní sila herní ruky

SCH ... statistické charakteristiky

Výsledky výpočtů základních statistických charakteristik sledovaných proměnných charakterizují výzkumné soubory juniorských tenistů a tenistek ve věku 11-12 let z hlediska úrovně základních antropometrických znaků (tenisté: tělesná výška, $\mathrm{V}=155,10 \pm 7,62 \mathrm{~cm}$, hmotnost, $\mathrm{H}=43,50 \pm 6,68 \mathrm{~kg}$; tenistky: tělesná výška, $\mathrm{V}=154,60 \pm 6,94 \mathrm{~cm}$, hmotnost, $\mathrm{H}=43,49 \pm 7,17 \mathrm{~kg}$ ) a silových parametrů (tenisté: maximální síla herní ruky, MS $=25,14 \pm 4,59 \mathrm{kp}$, relativní síla herní ruky, RS $=0,58 \pm 0,09$, tenistky: maximální síla herní ruky, $\mathrm{MS}=23,08 \pm 4,61 \mathrm{kp}$, relativní síla herní ruky, $\mathrm{RS}=0,53 \pm 0,09$ ).

$\mathrm{Z}$ výsledků uvedených $\mathrm{v}$ tabulce 1 je zřejmé, že rozdíly středních hodnot souborů tenistů a tenistek ve věku 11-12 let jsou poměrně malé, obdobně je tomu i z hlediska variability výsledků. Posouzení věcné významnosti rozdílů středních hodnot pomocí Cohen's d je uvedeno v tabulce 2 .

Tabulka 2. Posouzení věcné významnosti intersexuálních rozdílů

\begin{tabular}{|l|c|c|c|c|c|}
\hline \multirow{2}{*}{ Soubor/SCH } & \multicolumn{2}{|c|}{ Tenisté } & \multicolumn{2}{c|}{ Tenistky } & \multirow{2}{*}{$\begin{array}{c}\text { Cohen's d, } \\
\text { hodnocení efektu }\end{array}$} \\
\cline { 2 - 5 } & $\mathbf{M}$ & SD & M & SD & 0,07 (žádný) \\
\hline Výška (cm) & 155,10 & 7,62 & 154,60 & 6,94 & $\mathbf{0 , 0 0}$ (žádný) \\
\hline Hmotnost (kg) & 43,50 & 6,68 & 43,49 & 7,17 & $\mathbf{0 , 4 5}$ (malý) \\
\hline MS (kp) & 25,14 & 4,60 & 23,08 & 4,61 & $\mathbf{0 , 5 6}$ (střední) \\
\hline RS & 0,58 & 0,09 & 0,53 & 0,09 & $\mathbf{n}$ \\
\hline
\end{tabular}

Vysvětlivky: viz tabulka 1

Posouzení věcné významnosti rozdílů středních hodnot souboru tenistek a tenistů pro jednotlivé proměnné pomocí hodnot Cohenova d neprokázalo žádný rozdíl v intersexuálních diferencích v př́ipadě tělesné výšky $(\mathrm{d}=0,07)$ a hmotnosti $(\mathrm{d}=0,00)$, malý rozdíl v úrovni maximální síly herní ruky tenistů a tenistek $(\mathrm{d}=0,45)$ a střední rozdíl v relativní síle herní ruky $(\mathrm{d}=0,56)$.

Míra závislosti mezi sledovanými proměnnými (výška, hmotnost, maximální a relativní síla herní ruky) byla (vzhledem k prokázané normalitě výzkumných dat) zjišt'ována pomocí Pearsonova korelačního koeficientu, jehož hodnoty jsou uvedeny v tabulce 3 . Věcná významnost závislostí byla posouzena pomocí hodnoty koeficientu determinace $\mathrm{r}^{2}$ (Blahuš, 2000).

Tabulka 3. Hodnoty korelačního koeficientu (posouzení věcné významnosti)

\begin{tabular}{|l|c|c|c|c|c|c|c|}
\hline Hoši & H & MS & RS & Dívky & H & MS & RS \\
\hline $\mathbf{V}$ & $0,71^{* *}$ & $0,59^{* *}$ & 0,00 & $\mathrm{~V}$ & $0,75^{* *}$ & $0,55^{* *}$ & $-0,12$ \\
\hline $\mathbf{H}$ & & $0,59^{* *}$ & $-0,41^{*}$ & $\mathrm{H}$ & & $0,64^{* *}$ & $-0,25$ \\
\hline MS & & & $0,36^{*}$ & SM & & & $0,58^{* *}$ \\
\hline
\end{tabular}

Vysvětlivky:

$V$... tělesná výška

$H$... tělesná hmotnost

MS ... maximální síla herní ruky

$R S$... relativní sila herní ruky

$r^{2} \ldots$ koeficient determinace

***... vysoký efekt

**... střední efekt

*... nízký efekt 
Posouzení věcné významnosti závislostí mezi sledovanými proměnnými prokázalo závislost u souboru tenistů mezi tělesnou výškou a hmotností $\left(r=0,71, \mathrm{r}^{2}=0,50\right.$; střední efekt), dále mezi výškou a maximální sílou herní ruky $\left(\mathrm{r}=0,59, \mathrm{r}^{2}=0,35\right.$; střední efekt) a mezi hmotností a maximální sílou $\left(\mathrm{r}=0,59, \mathrm{r}^{2}=0,35\right.$, střední efekt). Nízká úroveň závislosti byla zjištěna mezi maximální a relativní silou $\left(\mathrm{r}=0,36, \mathrm{r}^{2}=0,13\right.$; nízký efekt) a také - ale negativní - mezi hmotností a relativní silou $\left(\mathrm{r}=-0,41, \mathrm{r}^{2}=0,17\right.$, nízký efekt). Závislost mezi výškou a relativní silou nebyla prokázána $(\mathrm{r}=0,0)$.

U souboru tenistek byla prokázána věcně významná závislost mezi tělesnou výškou a hmotností $\left(\mathrm{r}=0,75, \mathrm{r}^{2}=0,56\right.$; střední efekt), dále mezi hmotností a maximální sílou herní ruky $\left(\mathrm{r}=0,64, \mathrm{r}^{2}=0,41\right.$, střední efekt) a rovněž mezi maximální a relativní silou $\left(0,58, \mathrm{r}^{2}=0,34\right.$; střední efekt). Nízká závislost byla zjištěna mezi výškou a maximální sílou $\left(\mathrm{r}=0,55, \mathrm{r}^{2}=0,30\right.$; nízký efekt). Závislost mezi hmotností a relativní silou $\left(\mathrm{r}=-0,25, \mathrm{r}^{2}=0,06\right)$ a tělesnou výškou a relativní silou nebyla prokázána $\left(\mathrm{r}=-0,12, \mathrm{r}^{2}=0,01\right)$.

\section{Diskuze}

Pro posouzení výsledků úrovně maximální síly sledovaných tenistů a tenistek ve věku 11-12 let uvádíme hodnoty některých publikovaných studií. Posouzení významnosti diferencí mezi publikovanými hodnotami maximální síly a výsledky námi sledovaných tenistů a tenistek bylo provedeno pomocí tzv. kritického rozdílu, jehož hodnota byla pro soubor tenistů a tenistek vypočítána $\mathrm{d}_{\text {krit }}=1,8$ kp (Měkota \& Blahuš, 1983; Zháněl et al., 2015). Reid et al. (2003) uvádějí pro věk 12 let střední úroveň síly herní ruky tenistů hodnotu $\mathrm{M}=24,0 \mathrm{kp}$, u tenistek pak $\mathrm{M}=25,0 \mathrm{kp}$. Sportovní server Topend Sport (www.topendsports.com/) uvádí pro hochy ve věku 11-13 let střední hodnotu $\mathrm{M}=21,6 \mathrm{~kg}$ a pro dívky $\mathrm{M}=18,1 \mathrm{~kg}$. Výrobce ručního dynamometru Grip D (Takei) uvádí pro hochy ve věku 11-12 let střední hodnotu $\mathrm{M}=23,0 \mathrm{kp}$, pro dívky $\mathrm{M}=21,2 \mathrm{kp}$, významný německý zdroj norem motorické výkonnosti (Beck a Bös, 1995) uvádí pro chlapce střední hodnotu $\mathrm{M}=23,2 \mathrm{kp}$ a pro dívky $\mathrm{M}=21,1 \mathrm{kp}$ (obojí ve věku 11-12 let). Gulías-González et al. (2014) uvádějí střední hodnoty ruční dynamometrie pro věk 12 let $\mathrm{M}=22,8 \mathrm{kp}$ (hoši a dívky dohromady). Výsledky námi sledovaných tenistů $(\mathrm{M}=25,1 \mathrm{kp})$ byly významně vyšší ve srovnání se všemi publikovanými údaji s výjimkou hodnot uváděných autory Reid, et al. (2003). Výsledky souboru sledovaných tenistek $(M=23,1$ kp) byly opět významně vyšší s výjimkou hodnot uváděných autory Reid, et al. (2003) a Gulías-González et al. (2014).

Intersexuální rozdíly mezi hráči a hráčkami jsou ovlivněny jak odlišnou tělesnou konstitucí, tak i rozdílným ontogenetickým vývojem, u dívek růstové pubertální zrychlení intenzivnější a kratší, končí kolem 13 let, zatímco u chlapců je v tomto věku teprve před vrcholem (Riegerová et al., 2006). Zjištěné výsledky potvrzují, že v námi sledovaném věkovém období 11-12 let ještě nedochází k diferenciaci vlivem pubertálního zrychlení, intersexuální diference základních antropometrických znaků mezi tenistkami a tenisty jsou nevýznamné. Diference mezi hodnotami jsou poměrně malé jak v prŕípadě maximální síly (nízký efekt), tak i v případě relativní síly (střední efekt). Předchozí výzkumu (Pačes et al., 2015) ve věkové kategorii 13-14 let prokázal naopak významné diference (s výjimkou tělesné hmotnosti) mezi tenisty a tenistkami jak v tělesné výšce, tak i v maximální a relativní síle).

Prokázaná středně významná závislost úrovně maximální síly na hmotnosti jak u tenistů $(0,59)$, tak i u tenistek $(0,64)$ podporuje názor některých autorů (Zatsiorsky, \& Kraemer, 2014), že vhodnější charakteristikou pro hodnocení silové úrovně je relativní síla. Potvrdilo se rovněž tvrzení obou autorů (Zatsiorsky \& Kraemer, 2014, že závislost maximální síly a hmotnosti člověka je u aktivně sportujících jedinců vždy těsná. Z toho lze odvodit, že zejména v juniorském věku umožňuje vyšší tělesná výška a hmotnost dosažení větší maximální síly, což může pozitivně ovlivňovat i sportovní výkonnost. Carrasco et al. (2010) uvádějí, že úroveň maximální síly měřena ručním dynamometrem je vyšší u dominantní ruky, a to jak u praváků, tak i u leváků. Podle autorů Hanten et al. (1999) dosahují muži vyšší úrovně síly než ženy, což bylo prokázáno i v našem předchozím výzkumu (Pačes et al., 2015) u tenistů ve věku 13-14 let, ve věkové kategorii 11-12 let byly zjištěny jen malé rozdíly.

\section{Závěry}

Posouzení věcné významnosti intersexuálních diferencí mezi tenisty a tenistkami prokázalo nevýzn- 
amný rozdíl v př́ípadě základních antropometrických znaků (tělesná výška a hmotnost), malý rozdíl v úrovni maximální síly herní ruky a střední rozdíl v úrovni relativní síle herní ruky (ve prospěch tenistů). Výsledky sledovaných tenistů byly (až na jednu výjimku) významně vyšší ve srovnání než hodnoty publikované (5 zdrojü), u souboru sledovaných tenistek byly výsledky opět významně vyšší s výjimkou hodnot dvěma autory (z pěti). U souboru tenistů byla prokázána střední úroveň závislosti mezi tělesnou výškou a hmotností, mezi výškou a maximální sílou herní ruky a mezi hmotností a maximální sílou. Nízká úroveň závislosti byla zjištěna mezi maximální a relativní silou a také - ale negativní - závislost mezi hmotností a relativní silou. Závislost mezi výškou a relativní silou nebyla prokázána. Obdobné výsledky byly prokázány i u souboru tenistek - byla prokázána střední úroveň závislosti mezi tělesnou výškou a hmotností, mezi hmotností a maximální sílou herní ruky a rovněž mezi maximální a relativní silou. Nízká závislost byla zjištěna mezi výškou a maximální sílou. Závislost mezi hmotností a relativní silou a tělesnou výškou a relativní silou nebyla prokázána.

\section{Literatura}

Beck, J., \& Bös, K. (1995). Normwerte motorischer Leistungsfähigkeit. Köln: Sport und Buch Strauss.

Blahuš, P (2000) Statistická významnost proti vědecké průkaznosti výsledků výzkumu. Česká kinantropologie, 4(2), 53-71.

Carrasco, L., Francisco, P., Floría, P., \& Jurado, G. (2010). Grip Strength in Young Top-level Table Tennis Players. International Journal of Table Tennis Sciences, 6, 64-66.

Gulías-González, R., Sánchez-López, M., Olivas-Bravo, Á., Solera-Martínez, M., \& Martínez-Vizcaíno, V. (2014). Physical Fitness in Spanish Schoolchildren Aged 6-12 Years: Reference Values of the Battery EUROFIT and Associated Cardiovascular Risk. J School Health, 84(10), 625-635.

Dovalil, J., Choutka, M., Svoboda, B., Hošek, V., Perič, T., Potměšil, J., Vránová, J., \& Bunc, V. (2012). Výkon a trénink ve sportu. Praha: Olympia.

Girard, O., Lattier, G., Micallef, J. P., \& Millet., G. P. (2005) Cganges in exersize charakteristic, maximal voluntary contraction, and explosive strenght during prolonged tennis playing. Br J Sports Med, 40, 521-526.

Handgrip Strength Norms (2015). Topend Sports [online]. Př́stup dne 26.10.2015, z http://www.topendsports.com/testing/ norms/handgrip.htm.

Hanten, W. P. (1999). Maximum Grip Strength in Normal Subjects from 20 to 64 Years of Age. Journal of Hand Therapy 12, 193-200.

Hohmann, A., Lames, M., \& Letzelter, M. (2010). Úvod do sportovního tréninku. (T. Studený, Trans.). Prostějov: Sport a věda. (Originál vydán 2007).

Innes, E., (1999). Handgrip strength testing: A review of the literature. Australian Occupational Therapy Journal, 46, 120-140.

Kanehisa, H., Kuno, S., \& Fukunaga,T. (2006). A 2-year study on mucsle size andy dynamic strenght in teenage tennis players. Scand J Med Sci Sports, 16, 93-101

Massey-Westrop, N., Rankin, W., Ahern, M., Krishnan, J., \& Hearn, T. C. (2004). Measuring grip strength in normal adults: reference ranges and a comparison of electronic and hydraulic instruments. Journal of Hand Surgery, 29/3, 514-519.

Měkota, K., \& Blahuš, P. (1983). Motorické testy v tělesné výchově. Praha: Státní pedagogické nakladatelství.

Pačes, J., Zháněl, J., Černošek, M., \& Vodička, T. (2015) Analysis of maximum and relative strength levels of junior male and female tennis players. In $10^{\text {th }}$ International conference on kinanthrolophy $10^{\text {th }}$ "Sport and Quality of Life (in press). Brno: Masarykova univerzita.

Reid, M., Quinn. A., \& Crespo, M. (2003). Strenght and Conditional for Tennis. London: International Tennis Federation.

Reid, M., \& Schneiker, K. (2008). Strength and Conditioning in tennis - current

research and practice. Journal of Science and Medicine in Sport, 11, 248-256.

Riegerová, J., Přidalová, M., \& Ulbrichová, M. (2006). Aplikace fyzické antropologie v tělesné výchově a sportu (příručka funkční antropologie). Olomouc: HANEX.

Roetert, P., \& Kovacs, M. (2011). Tennis anatomy. Champaign, IL: Human Kinetics.

Schönborn, R. (2012). Strategie a taktika v tenisu. Teorie, analýzy a problematika - zdůvodněné ze zcela nového úhlu pohledu. (T. Studený, Trans.). Prostějov: Sport a věda. (Originál vydán 2012).

Zatsiorsky, V. M., \& Kraemer, W. J. (2014). Silový trénink: Praxe a věda. (T. Studený, Trans.). Praha: Mladá fronta. (Originál vydán 2006).

Zháněl, J., Balaš, J., Trčka, D., \& Shejbal, J. (2000). Diagnostika výkonnostních předpokladů v tenise. Tenis, 11(3), 18-19.

Zhanel, J. Černosek, M., Zvonar, M., Paces, J., \& Vodicka, T. (2015). Kraftdiagnostik bei tschechischen Elite-Tennisspielerinnen. In U. Granacher, Konferenz Krafttraining (p. 79). [Abstractband]. Potsdam: Universität Potsdam. 